\title{
On the Effect of Reciprocal Teaching Strategy on EFL Learners' Reading Proficiency
}

\author{
Seyyed Ali Ostovar-Namaghi \\ Shahrood University of Technology, Iran \\ Email: saostovarnamaghi@yahoo.com \\ Mohammad-Reza Shahhosseini \\ Islamic Azad University, Garmsar Branch, Iran
}

\begin{abstract}
This study aimed at exploring the comparative effect of reciprocal teaching on EFL learners' reading proficiency. From the total population of freshmen at Shahrood University of Technology (SUT) who enrolled for the General English course, 120 students were randomly selected. The researcher administered and scored the Comprehensive English Language Test (CELT) and then selected subjects whose raw scores were one standard deviation above and below the arithmetic mean. All in all, 70 students were paired based on their rank score. Subjects of the same rank were randomly assigned to experimental and control groups and were instructed through transmission and reciprocal models respectively. A second test, i.e. TOFL, was used for pre-test and post-test. The results showed: (1) a significant (at the 0.05 level) difference in how the control and experimental groups performed in the post test; (2) a significant (at the 0.05 level) difference in how the experimental group performed in pre-test and post test.
\end{abstract}

Index Terms — reciprocal teaching, transmission model, experimental research

\section{INTRODUCTION}

According to Doolittle, et al. (2006), the general methodology of reciprocal teaching involves the instructor and students reading a section of the text in small groups. The instructor then leads a discussion of the text, while modeling appropriate reading comprehension strategies. During this dialogue and modeling process, the instructor encourages students to ask questions of both the text and strategies. The instructor uses this dialogue to foster both reading comprehension and strategic cognition. This general process of reading, dialoguing, and clarifying, continues throughout the length of the text. However, as students become more facile with the dialogue process and the reading comprehension strategies, the instructor begins to have students take the role of instructor or dialogue leader. As students begin to lead the dialogue process, the instructor assumes the role of guide or facilitator, rather than a leader.

Researchers gave several reasons why teachers should choose reciprocal teaching as an appropriate instructional approach to help students comprehend difficult text. Reciprocal teaching allows the students to monitor their progress and assume the ultimate responsibility for their learning from the text regardless of the content covered in a particular class (Slater \& Horstman, 2002). This method allows students to take ownership over their reading and learning (Hashey \& Connors, 2003). By gaining control of their learning while they read, students also have the potential to become better self-regulators of their reading (Hacker \& Tenent, 2002) Reciprocal teaching drastically improves the quality of classroom discussions since all students are able and expected to participate and provide input and thought into the group dialogue (Hashey \& Connors, 2003). When combined with the use of reading journals and writing prompts, reciprocal teaching has also been shown to be very effective in helping students to become more proficient writers (Slater \& Horstman, 2002). Research results emphasized the benefits of using reciprocal teaching in:

- teaching students at different levels, and in different subjects regardless of students' abilities (Myers, 2006);

- helping students acquire vocabulary and reading comprehension for low-achievers in elementary grades in Basic level (Todd, 2006);

- improving students' achievement in standardized tests (Brand-Gruwel, Aarnoustes, \& Van Den Bos, 1998).

- developing students higher order thinking skills (Hacker \& Tenent, 2002).

Barton, et al. (2002) recommends that teachers incorporate reading and learning strategies that help students activate prior knowledge, make sense of unfamiliar text styles, and master difficult vocabulary. Radcliffe, et al. (2004) demonstrated that explicit strategies promote engagement of prior knowledge and self monitoring in students while reading. Barton, et al. (2002) explains that reading and learning are constructive processes: each learner actively draws on prior knowledge and experience to make sense of new information. The more knowledge and skills that students bring to a text, the better they will learn from and remember what they read. Best, et al. (2005) explains that when students make connections while reading through inferential thought, deep-level comprehension will follow. Deep comprehension, as described by Best, et al. (2005) is requiring more than interpretations of sentences. 
Brown and Palinscar (1989) have noted that reciprocal teaching is explained by three related theories of guided learning: Vigotsky's zone of proximal development (Vigotsky, 1978), Proleptic teaching (Wertsch \& Stone, 1976; Rogoff \& Gardner, 1984), and expert scaffolding (Wood, Bruner, \& Ross, 1976).

Vigotsky (1978) observed that a child has two developmental levels. One is the actual developmental level, the level at which children can independently deal with tasks. The other is the level of potential development, or the level at which a child can solve a problem with the assistance of a teacher or in collaboration with other children. The zone of proximal development is the area between "the actual development level of the child and the level of potential development" (Vigotsky, 1978, pp. 85-86). Learners can push themselves from the actual developmental level to the potential level or learn beyond their actual development level with explicit scaffolding through social interaction until they internalize the strategies (Rosenshine \& Meister, 1994).

Wood, Bruner, and Ross (1976) were the first to use the term scaffolding in its educational sense. According to Greenfield (1994), scaffolding teaching is adapted to the learner's current learning state; when the learners' skills are developed, the teachers scaffolding is decreased, and if the text is difficult, greater assistance and feedback are given to the students in order to shape their understanding. However, the teacher acts as a facilitator after the students do not need much help. Scaffolding is eventually internalized and thus promotes the independent performance of reading skills. Scaffolding has been variously defined as:

- a process that enables a child or novice to solve a problem, carry out a task or achieve a goal which would be beyond his unassisted efforts (Rogoff, 1990, p.93);

- what teachers say and do to enable children to complete complex mental tasks they could not complete without assistance" (Pearson \& Fielding, 1991, p. 842);

- a process whereby a teacher monitors student s' learning carefully and steps in to provide assistance on an asneeded basis (Wharton-MacDonald, 1998, et al, p.116); and

- a temporary supportive structure that teachers create to assist a student or a group of students to accomplish a task that they could not complete alone (Graves, Waltts, \& Graves, 1994. p.44).

The important feature of proleptic teaching is the transfer of responsibility from teacher to students. The teacher explains and models the process of solving problems, and while decreasing his or her role, transfers the responsibility of solving problems to the students (Rogoff \& Gardner, 1984). Proleptic teaching is defined as teaching in anticipation of competence (Brown, Campione, Ferrrara, Reeve, \& Palinscar, 1991). A proleptic teacher could be described as one who has high expectations and believes in his or her student s' ability to meet them. Regardless of a student s' perceived ability or level of intelligence, the teacher assumes that the student is capable and will eventually be able to accomplish the task as an expert would. In contrast, instruction that embodies a hierarchical stepwise pattern (Gagne, 1985) communicates to the children that all a teacher expects is the mastery of one point in development, which, according to Palinscar and Herrenkohl (2002), is an inefficient use of instructional time.

Despite the pedagogical implications of reciprocal teaching and its strong theoretical foundations, in many EFL contexts, including Iran, banking system is the dominant model of language education. Compared with reciprocal teaching, this system defines:

- the textbook as the only reliable source of knowledge;

- teachers as the mechanical channels through which knowledge is transmitted to the learners;

- learners as empty vessels waiting to be filled.

This conception of teaching and learning is limited and limiting. It is limited in that it produces a host of well-trained parrots who see their role as echoing the content of the book. It is limiting in that it makes students take the truth value of the content of the textbook for granted since it inculcates the idea that the right answer comes from the book rather than from reasoning. Far from focusing on the transmission of information, the theoretical underpinnings of reciprocal teaching, i.e. zone of proximal development, proleptic teaching and scaffolding, focus on the construction of meaning in the dialogical process of interaction between the teacher and the learners. Taking the theoretical foundations of reciprocal teaching into account, the researchers believe that substituting reciprocal teaching with the transmission model can significantly improve students reading comprehension deficiencies in EFL contexts including Iran.

\section{A. Purposes of the Study}

Based on their experience in language teaching in EFL contexts, the researchers hypothesize that reciprocal teaching is more effective than traditional transmission model in teaching reading proficiency. However, this perceived efficiency of reciprocal teaching may be due to chance factors or error of measurement. Thus the study aims at testing the following null hypotheses:

Ho $_{1}$ : Reciprocal teaching and transmission model have the same effect on students' reading proficiency, i.e. $\mu \mathrm{R}=\mu \mathrm{T}$

$\mathbf{H O}_{2}$ : Reciprocal teaching has no significant effect on EFL learners' reading proficiency, i.e. $\mu \mathrm{R} 1=\mu \mathrm{R} 2$

\section{B. Limitations of the Study}

Although the study was true experimental in design, it may suffer from external validity since the results may not be generalized beyond the accessible population, i.e. students taking General English at Shahrood University of Technology (SUT). Moreover, although we believe that random selection and random assignment evenly distribute 
initial differences in entry behavior and nullifies the effect of extraneous and intervening variables, claiming that the changes in the dependent variable, i.e. reading proficiency is brought about solely by the independent variable, i.e. reciprocal teaching is exaggerated for human subjects. Finally, the results of this study and other experimental studies should be generalized cautiously since we are generalizing the results of experimental conditions to non-experimental conditions. Compared with chemical substances, human subjects may behave quite differently under experimental and natural conditions.

\section{RESEARCH METHOD}

\section{A. Research Context}

This study took place in SUT located in Semnan province, which has a population of nearly 10,000 students. Students taking General English at SUT comprise the accessible population of this study. Compared with students of humanities, students at universities on technology including SUT enjoy a good command of English. It is also worth noting that taking laboratory is an inseparable part of General English at this University. Although General courses are presented by different teacher, the laboratory is offered only by one teacher, i.e. one of the researchers. And it is this exclusive feature that made random selection and random assignment possible. Since universities of technology in Iran have conditions and students of similar background, the target population of this study can be taken as Universities of Technology in Iran.

\section{B. Subjects}

From the total population of freshmen at SUT who enrolled for the General English course, 120 students were randomly selected. They all took the Comprehensive English Language Test (CELT). Having analyzed students' scores in CELT, the researcher selected students whose raw scores were one standard deviation above and below the arithmetic mean. Moreover, he used the results of this test to randomly assign students of the same rank to experimental and control groups. Students who did not fit the matching procedure were left out. All in all, 70 students, both male and female, aging between 18-20 years were randomly assigned to experimental and control groups.

\section{Research Instrument}

This study is based on the reading sub-test of two instruments: Comprehensive English Language Test (CELT); and Test of English as a Foreign Language (TOEFL). Both tests were administered to a similar sample to calculate their reliability. Both tests showed an acceptable reliability index $(\alpha=0.79)$. The first test, i.e. CELT, was used to homogenize the subjects and match entry behavior of subjects in the experimental and control groups. The second test, i.e. TOFL, was used for pre-test and post-test. More specifically, the study relies on the results of pre-test and post-test with the same test, i.e. TOEFL. The pre and post-test reading comprehension test consisted of 50 questions spread over 5 texts (see Appendix A). The post-test was administered to the subjects after one semester of instruction.

\section{Operational Definition of Variables}

The research hypothesis in this study aims at specifying the effect of reciprocal teaching, i.e. the independent variable, on reading proficiency, i.e. the dependent variable. In this study reading proficiency refers to students' scores in the reading section of the TOEFL. The independent variable or treatment refers to involving students in the dialogical process of understanding the text and the reciprocal teaching strategies. In the step-by-step process of reciprocal teaching the teacher:

- encouraged the students to read a section of the text in small groups;

- lead a discussion of the text;

- modeled appropriate reading comprehension strategies.

- encouraged students to ask questions of both the text and strategies;

- used this dialogue to foster both reading comprehension and students awareness of the strategies;

- continued the process of reading, dialoguing, and clarifying throughout the length of the text;

- began to have students take the role of instructor or dialogue leader as they became more facile with the dialogue process and the reading comprehension strategies; and

- assumed the role of guide or facilitator, rather than a leader.

\section{E. Data Collection and Analysis}

Having matched the students in control and experimental groups, the researchers taught the experimental group via reciprocal teaching and the control group via the transmission model which aims at form-focused activities that aim at enabling learners receive the meaning of the text. Prior to treatment, however, the TOEFL test was administered to both groups to make sure that there was no significant difference in students' performance in the test. Paired-sample t-test of significance showed that initially the two groups did not have any significant difference. After treatment, the same test was used as the post-test to test the following null hypothesis:

H0$_{1}$ : Reciprocal teaching and transmission model have the same effect on students' reading proficiency, i.e. $\mu \mathrm{R}=\mu \mathrm{T}$

$\mathbf{H 0}_{2}$ : Reciprocal teaching has no significant effect on EFL learners' reading proficiency, i.e. $\mu \mathrm{R} 1=\mu \mathrm{R} 2$ 
In this formulation $\mu \mathrm{R}$ is the estimated population mean of the experimental group, i.e. the group taught through reciprocal teaching, $\mu \mathrm{T}$ is the estimated population mean of the control group, i.e. the group taught through transmission model, $\mu \mathrm{R} 1$ is the estimated population mean of experimental group in pre-test, and $\mu \mathrm{R} 2$ is the estimated population mean of the experimental group in post-test

\section{RESULTS}

The results of the study is based on three pairs of analysis: pair 1, shows the performance of the control and experimental groups prior to experimental treatment to account for entry behavior; pair 2 aims at comparing the effect of reciprocal teaching and transmission model as measured by the post-test; and pair 3 shows the proficiency gain related to experimental treatment. In all cases paired samples t-test was used since the subjects were assigned to experimental and control groups through a matching process, i.e. subjects of the same ranks were randomly assigned to the two groups. The results of the analysis are shown in table 1.

TABLE 1.

PAIRED SAMPLES T-TEST RESULTS

\begin{tabular}{|c|c|c|c|c|c|c|c|c|c|}
\hline & & \multicolumn{5}{|c|}{ Paired Differences } & \multirow[b]{3}{*}{$\mathrm{t}$} & \multirow[b]{3}{*}{ df } & \multirow{3}{*}{$\begin{array}{l}\text { Sig. } \quad(2 \\
\text { tailed })\end{array}$} \\
\hline & & \multirow[b]{2}{*}{ Mean } & \multirow{2}{*}{$\begin{array}{l}\text { Std. } \\
\text { Deviation }\end{array}$} & \multirow{2}{*}{$\begin{array}{ll}\text { Std. Error } \\
\text { Mean }\end{array}$} & \multicolumn{2}{|c|}{$\begin{array}{l}95 \% \text { Confidence Interval } \\
\text { of the Difference }\end{array}$} & & & \\
\hline & & & & & Lower & Upper & & & \\
\hline Pair 1 & Pre control - Pre experimental & -1.30000 & 5.99511 & 1.09455 & -3.53861 & .93861 & -1.188 & 34 & .245 \\
\hline Pair 2 & Post control - Post experimental & -5.46667 & 5.99847 & 1.09517 & -7.70653 & -3.22680 & -4.992 & 34 & .000 \\
\hline Pair 3 & Pre experimental - Post experimental & -4.63333 & 3.64345 & .66520 & -5.99382 & -3.27285 & -6.965 & 34 & .000 \\
\hline
\end{tabular}

Table 1 clearly shows that initially the two groups were not significantly different since the calculated t-statistic is $\mathrm{t}=1.188$ and $\mathrm{p}$-value is much bigger than 0.05 in pair 1 . The table also clearly shows that the first null hypothesis is rejected since the calculated t-statistic is $t=4.992$ and $\mathrm{p}=.000<0.05)$. A small $\mathrm{p}$-value such as this indicates the rejection of the null hypothesis and leads to the conclusion that the average difference in means across the paired observations is not zero, i.e., there is evidence of a significant (at the 0.05 level) difference in how the control and experimental groups performed in the post test. Therefore, $\mathrm{H} 0$ is rejected. This means compared with the transmission model, reciprocal teaching yielded significantly higher results.

Table 1 also shows that the second hypothesis is rejected since, as shown in pair 3 , the calculated t-statistic is $t=$ 6.965 and $p=.000<0.05)$. A small $p$-value such as this indicates rejection of the null hypothesis and leads to the conclusion that the average difference in means across the paired observations is not zero, i.e., there is evidence of a significant (at the 0.05 level) difference in how the experimental group performed in pre-test and post test. Therefore, $\mathrm{H} 0$ is rejected in favor of $\mathrm{H} 1$.There is a significant difference in performance between the performance of experimental group in pre-test and post-test. That is, experimental treatment or reciprocal teaching had a significant effect on learners' reading proficiency as measured by the TOEFL test.

\section{DISCUSSION}

In this study, the subjects were trained to employ the four key strategies and to know what strategies to use, and when, why, and how to use each of them. They learned to predict, to generate questions, to identify the main idea of a paragraph, to clarify unclear words, phrases, or sentences, and to summarize their reading. The four key strategies helped them overcome difficulties when reading texts as they planned and monitored their comprehension, and evaluated their planning and its outcome. The results clearly showed that despite their homogeneous performance in pre-test, the experimental group outperformed the control group in the post-test. This shows that reciprocal teaching has the edge over transmission model. Going beyond statistical significance, one can relate the differential effect of reciprocal teaching to the dialogical process of constructing the meaning of the text and the strategies which lead to the active involvement of the learners. Although initially, teacher-student interaction may dominate, as the course progresses gradually student-student interaction is more dominant. Having moved towards independence, learners transfer their training beyond the classroom borders. Thus the differential effect of reciprocal teaching may partially be related to student-student interaction outside the classroom.

Compared with reciprocal teaching which demands active construction of meaning, the transmission model defines learners' roles as nothing but the passive recipients of information. in addition to being passive students in the control group, are totally dependent on the teachers. Thus not only are they deprived from the meaningful activities of reciprocal teaching which are conducive to language development, they are also deprived of their own potential for interaction outside the classroom because the transmission model never provided them with any opportunity to interaction with each other.

In addition to its obvious edge over the transmission model in terms of proficiency gain, reciprocal teaching is more in tune with the heartbeat of language. Rather than being a unidirectional mechanism for receiving information, as it is 
supposed by the traditional transmission model, language is mechanism for constructing meaning in the dialogical process of negotiation and interaction with the text and with the others. Taking these merits of reciprocal teaching into account, the researcher recommends the use of this method as a substitute for traditional models in EFL contexts.

\section{IMPLICATIONS AND SUGGESTIONS FOR FURTHER RESEARCH}

In addition to yielding significantly higher proficiency gains in language learners, this approach, with its solid theoretical basis, has profound implications for all stakeholders. More specifically, it:

- redefines teachers' role as a facilitator of negation for meaning construction rather than a mechanical channel for unidirectional transmission of information;

- redefines learners roles as those who take charge of their learning and move towards autonomy rather than empty vessels waiting to be filled as defined by the transmission model;

- relocates the locus of meaning from the text to the dialogue. That is, rather than residing in the texts, meaning resides in the dialogical process of classroom interaction;

- paves the way for future democracy since democratic citizens actively create the meanings of roles, responsibility and rights through interacting and negotiating with others rather than passively accept them hierarchically;

- invites syllabus developers to select texts that are subjective to multiple interpretation rather than texts that convey one single objective meaning; and

- redefines language assessment as continuous and performance-based rather than final and paper-and-pencil-based.

Despite the profound pedagogical and social implications of reciprocal teaching, we cannot generalize the findings until it is replicated in other similar contexts, i.e. other universities presenting general English under similar conditions to SUT. Since private language schools operate under different conditions and purposes, the findings cannot be generalized to these institutes. Thus further studies need to be carried out to test the efficiency of this method beyond university contexts. Moreover, since learners perceptions of the method, affect their performance in the classroom, the field is in urgent need of qualitative studies that aim at theorizing learners' perceptions and perspectives concerning reciprocal teaching.

\section{REFERENCES}

[1] Barton, M, L., Heidema, C., \& Jordan, D. (2002). Teaching reading in mathematics and science. Educational Leadership, 8(3), 24-28.

[2] Best, R. M., Rowe, M., Ozuro, Y., \& McNamara, D. S. (2005). Deep-level comprehension of science texts: The role of the leader and the text. Topics in Language Disorders, 25(1), 65-83.

[3] Brand- Gruwel, S., Aarnoutse, C., \& Van Den Bos, K. (1998). Improving text comprehension strategies in reading and listening setting. Learning and Instruction 8 (1), 63-81.

[4] Brown, A., \& Palinscar, A. (1989). Guided, cooperative learning and individual knowledge acquisition. In L. B. Resnick. (Ed.). Knowing, learning, and instruction: Essays in honor of Robert Glaser (pp. 393-451). Boston: Allyn \& Bacon.

[5] Brown, A. L., Campione, J. C, Ferrare, R. A., Reeve, R. A., \& Palinscar, A. S. (1991). Interactive learning and individual understanding: The case of reading and mathematics. In L. T., Landsman (Ed.), Culture, schooling, and psychological development: Vol. 4. Human development (pp. 136-170). Norwod, NJ: Ablex Publishing Corporation.

[6] Doolittle, P. E., Hicks, D., Triplett C. Nichols, W. D., \& Young, C. A. (2006). Reciprocal teaching for reading comprehension in higher education: A strategy for fostering the deeper understanding of the texts. International Journal of Teaching and Learning in Higher Education, 17(2), 106-118.

[7] Gagne, R. M. (1985). The conditions of learning ( $4^{\text {th }}$ ed.). New York: Holt, Rinehart, \& Winston.

[8] Graves, M. F., Watts, S., \& Graves, B. B.(1994). Essential of classroom teaching: Elementary reading. Boston: Allyn \& Bacon.

[9] Greenfield, P.M. (1984). A theory of the teacher in the learning activities of every life. In B. Rogoff \& J. Lave(Eds), Every day cognition: Its development in social context (pp. 117-138). Cambridge, Ma: Harvard University Press.

[10] Hacker, D \& Tenet, A. (2002). Implementing reciprocal teaching in the classroom: Overcoming obstacles and making modifications. Journal of Educational Psychology, 94 (4). 699-718.

[11] Hashey, M. Conners, D. (2003). Learn from our journey: Reciprocal teaching action research. The Reading Teacher, 57(3), 224-232.

[12] Myers, P. (2006). The princess storyteller, Clara Clarifier, Quincy Questioner, and the Wizard: reciprocal teaching adapted for kindergarten students. The Reading Teacher 59 (4), 48-57.

[13] Palinscar, A. S., \& Herrenkohl, L. R. (2002). Designing collaborative learning contexts. Theory into Practice, 41(1), 26-32.

[14] Radcliffe, R., Caverly, D., Peterson, C., \& Emmons, M. (2004). Improving textbook reading in a middle school science classroom. Reading Improvement, 41 (3), 145-156.

[15] Rogoff, B., \& Gardner, W.P. (1984). Adult guidance of cognitive development. In B. Rogoff, \& J. Lave (Eds.).Everyday cognition: Its development in social context (pp. 134-157). London: Cambridge University Press.

[16] Rogoff, B. (1990). Apprenticeship in thinking. New York: Oxford University Press.

[17] Rosenshine, B., Meister, C. (1994). Reciprocal teaching: A review of the research. Review of Educational Research, 64(4), 479-530.

[18] Slater, W. \& Horstman, F. (2002). Teaching reading and writing to struggling middle school and high school students: The case for reciprocal teaching. Preventing School Failure, 3(2), 163-166. 
[19] Todd, R.B., \& Tracey, C.H. (2006). Reciprocal teaching and comprehension: A single subject research study. Published master Thesis, Kean University, United States. Retrieved April 15, 2007, from http://www.eric.ed.gov.

[20] Vygotsky, L.S. (1978). Mind in Society: The development of the higher psychological processes. Cambridge, MA: Harvard University Press.

[21] Wharton-McDonald, R., Pressley, M., \& Hampston, J. M. (1998). Literacy instruction on nine first-grade Classrooms: Teacher characteristics and student achievement. Elementary School Journal,99, 101-128.

[22] Wood, D. J., Bruner, J. s., \& Ross, G. (1976). The role of tutoring in problem solving. Journal of Child Psychology and Psychiatry, 17,89-100.

[23] Wretsch, J.V., \& Stone, C. A. (1976). A social interaction analysis of learning disabilities remediation. Paper presented at the International Conference of the Association for children with Learning Disabilities, San Francisco.

Seyyed Ali Ostovar-Namaghi was born in 1969. Presently, he runs EAP courses at Shahrood University of Technology, Iran. His chief area of research interest is language teacher education. He has published in a number of leading peer-reviewed journals including the Reading Matrix, Teacher Education Quarterly, the Qualitative Report, and the Asian EFL Journal.

Mohammad-Reza Shahhosseini received his MA in TEFL from Islamic Azad University, Gramsar branch in 2011. At the time being he has a tenured position at Shahrood University of Technology where he runs language laboratory. His area of research interest is innovations in language teaching. 